\title{
A Case of Squamous Cell Carcinoma of Skin Subsequent to Subcutaneous Foreign Body
}

\author{
Mubashir $S^{1}$, Anwar $P^{2}$, Hassa I $I^{3}$, Arif $T^{4}$ \\ ${ }^{1}$ Lecturer, ${ }^{2}$ Senior Resident, ${ }^{3}$ Professor and Head, \\ ${ }^{4}$ Postgraduate scholar \\ Postgraduate Department of Dermatology, STD \\ \& Leprosy, Govt. Medical College, Srinagar, J \& \\ $K$, India.
}

\author{
Address for correspondence \\ Dr Parvaiz Anwar \\ Senior Resident, Postgraduate Department of \\ Dermatology, STD \& Leprosy \\ Govt. Medical College, Srinagar, J \& K, India. \\ E-mail: parvaizanwar@gmail.com
}

\section{Citation}

Mubashir S, Anwar P, Hassa I, Arif T. A case of squamous cell carcinoma of skin subsequent to subcutaneous foreign body. NJDVL 2014; 12(1): $53-55$.

\section{Introduction}

Squamous cell and basal cell carcinoma are the most important non melanoma skin cancers and exposure to ultraviolet radiation is the most important risk factor for the development of these, besides other risk factors including foreign body. ${ }^{1-}$

${ }^{4}$ In Kashmir, because of continuous exposure to Kangri, fire pot used for warming during winter, a specific type of NMSC called Kangri cancer develops usually on thighs after passing through the stages of erythema ab igne and bowen's disease. ${ }^{5}$ We report a case of SCC on inner thigh in an elderly Kashmiri female probably developing subsequent to subcutaneous non-metallic foreign body.

\section{Case report}

A 65 years old Kashmiri female, non diabetic, hypertensive, presented with 5 years duration of a small, single, dry, rough, asymptomatic skin lesion on left inner thigh. This was preceded, one month back, by a trivial trauma with penetration of dry piece of broom. Like all Kashmiri population, she has been in the habit of using Kangri for warmth for years together. The skin lesion progressed very gradually over the years and, being asymptomatic, was kept unattended. For last one month the lesion suddenly increased in size, became painful and started oozing. She was prescribed some oral and topical antibiotics by general practitioner but lesion continued its aggressive course till she consulted us. She has past history of hypertension for 15 years and is on regular medication. There is no other significant family and drug history. General physical and systemic examination was normal. Dermatological examination revealed a single well defined fungating exophytic growth, with crusting and sero-hemorrhagic exudation, on inner thigh of left side, measuring about $7 \mathrm{~cm} \times 6 \mathrm{~cm}$. It was 


\section{Case Report}

firm, non-tender, containing friable tissue, with indurated base (Figure 1). The skin on both inner thighs showed reticulate pigmentation (erythema $a b$ igne). There was no significant lymphadenopathy in inguinal or other areas. The routine investigations including complete hemogram, liver and kidney function tests, chest X-Ray, ultrasound abdomen/ pelvis, revealed no abnormality. With a clinical impression of squamous cell carcinoma, the patient was planned for wide surgical excision. The lesion was completely excised along with 1 centimeter margins and sent for histopathological examination (HPE). During excision, the subcutaneous tissue in the centre of the mass contained foreign body, a small piece of broom (Figure 2). The wound was closed with transposition flap technique (Figure 3). HPE under hematoxylin \& eosin stain showed thin epidermis with keratinized squamous tumour cells infiltrating the whole dermis, confirming the diagnosis of SCC (Figure 4).

\section{Discussion}

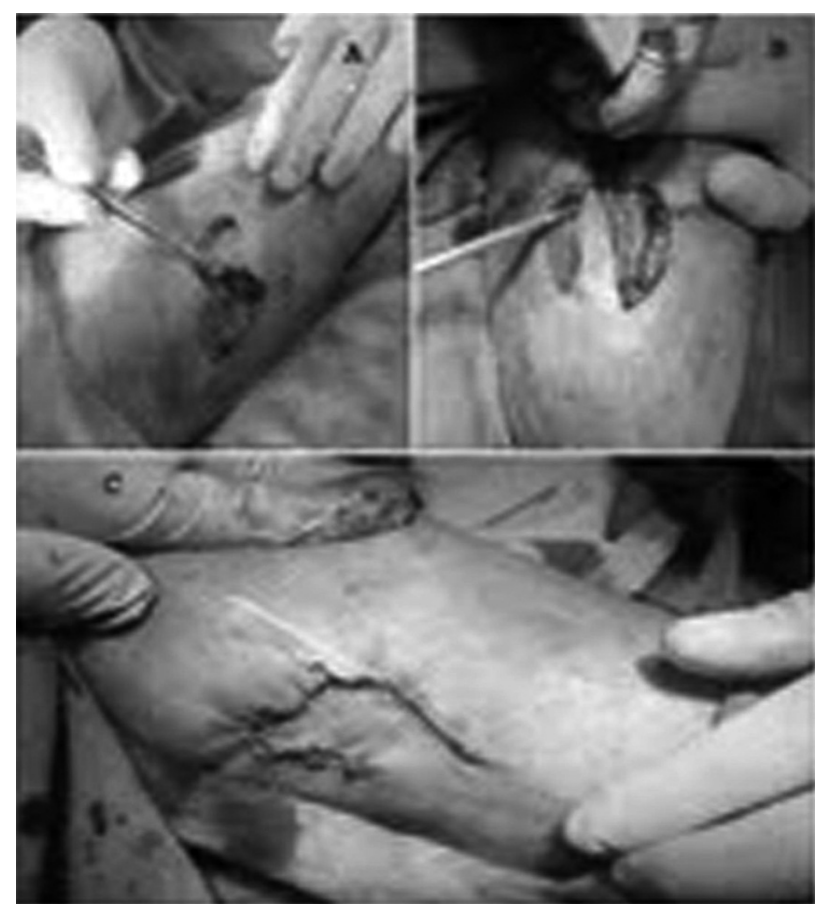

Figure 3: Lesion excised in Toto and closed with transposition flap.

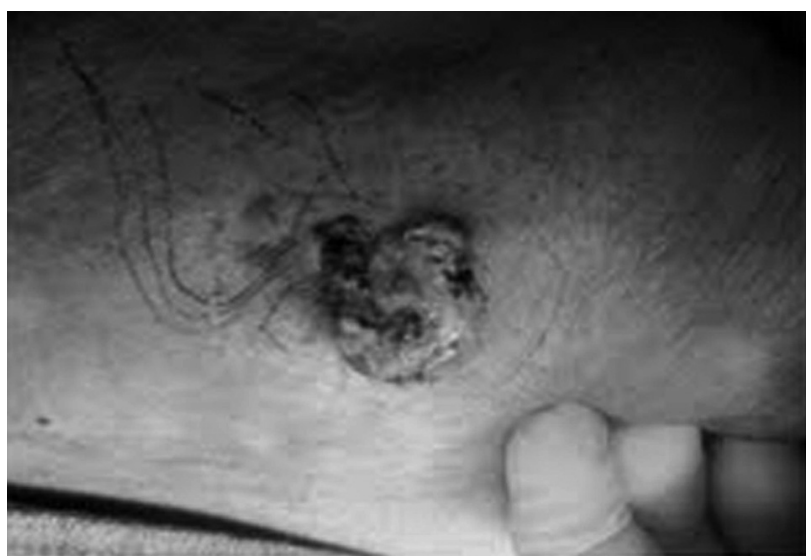

Figure 1: Friable, exophytic lesion of clinically suspected squamous cell carcinoma, with surrounding erythema $a b$ igne.

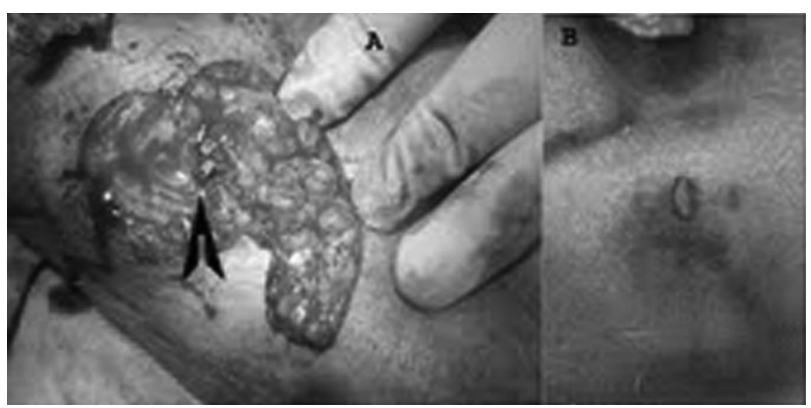

Figure 2: Non metallic foreign body, impacted in subcutaneous tissue in the centre of the growth
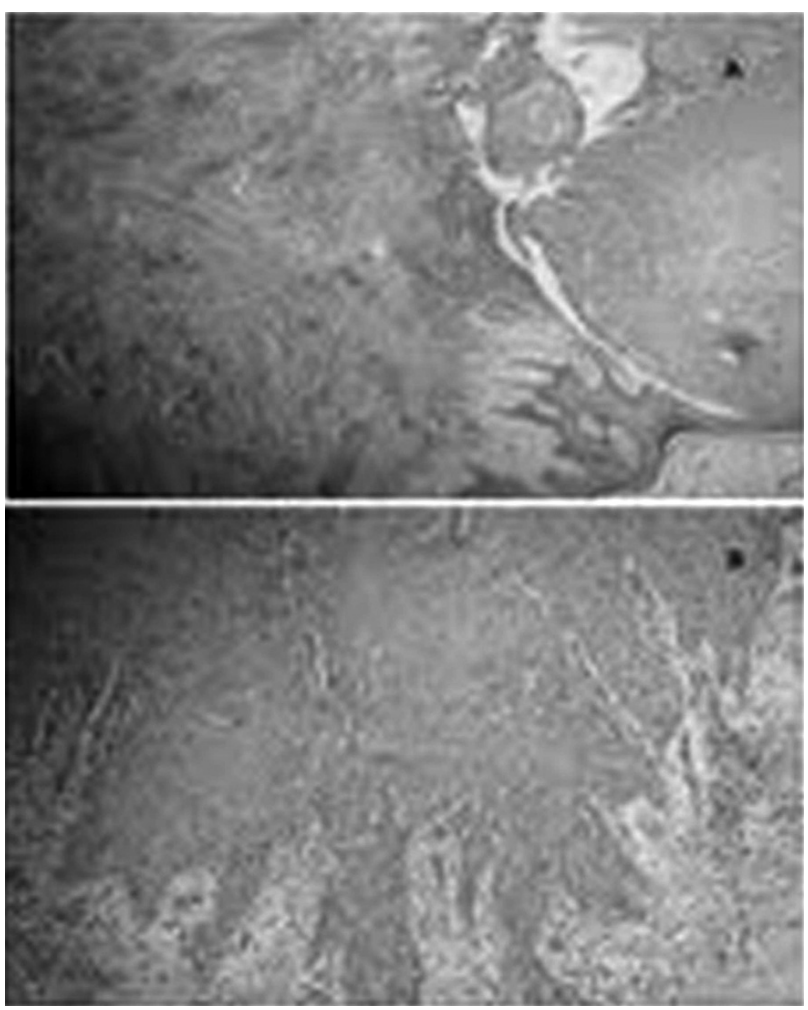

Figure 4: Photomicrograph showing thin epidermis with keratinized squamous tumour cells infiltrating whole dermis (H \& E; X10) 


\section{Case Report}

Besides exposure to ultraviolet radiation, other risk factors for NMSC include industrial exposure to oils and tar, chronic ulcers, draining osteomyelitis, burn scars (Marjolin ulcer), ionizing radiation, chronic irritation, sites of previous trauma, chronic inflammation, non-healing wounds and also foreign bodies. ${ }^{6,7}$

Etiopathogenesis of a cancer can be attributed to the above risk factors through many mechanisms such as spontaneous errors in DNA replication, inflammatory or cytotoxic carcinogenic materials, materials that directly injure DNA, radiation exposure and viral oncogenesis. Foreign body carcinogenesis in humans appears to be related to the chronic inflammation that results. ${ }^{8}$ Chronic inflammation causes an increased rate of cell turnover which is expected to increase the risk for a spontaneous replication error in DNA during cell division, although, other mechanism may play a role in foreign body-induced tumor. Inflammatory mediators released by inflammatory

\section{References}

1. Rieger UM, Kalbermatten DF, Wettstein R, Heider I, Haug M, Pierer G. Marjolin's ulcer revisitedbasal cell carcinoma arising from grenade fragments? J Plast Reconstr Aesthet Surg 2008; 61: 65-70.

2. Endo T, Hata J, Togashi S, Yanagibayashi S, Nakayama Y. Conjunctival squamous cell carcinoma of the orbit 40 years after enucleation. Ophthal Plast Reconstr Surg 2006; 22: 299-301.

3. Gökce MI, Süer E, Tangal S, Bedük Y. Squamous cell carcinoma of the bladder associated with chronic irritation related to a migrated intrauterine device. Scand J Urol Nephrol 2010; 44: 183-5.

4. Eric MN, Craig AC, Edward DS, Rebecca SF. Case of a squamous cell carcinoma associated with a subcutaneous foreign body. Osteopathic Family Physician 2012; 4: 29-32.

5. Sanyal B, Shastri SR, Hakim A. A clinical profile of skin cancer from Kashmir valley with special reference to Kangri cancer. J Clin Radiother Oncol 1989; 4: 31-6.

6. Murphy GF, Sellheyer K, Mihm MC. The Skin. In: Kumar V, Abbas AK, Fausto N, editors. cells at the inflammatory foci like tumor necrosis factor-alpha (TNF-á), interleukin-1â, matrix metalloproteins-9 (MMP-9), vascular endothelial growth factor (VEGF) have been implicated to act as promoters, besides the release of oxygen and nitrogen oxide free radicals from leukocytes which exhibit cytotoxic and mutagenic effects. ${ }^{8-10}$

Development of foreign body carcinogenesis is rarer in humans and has been well studied in animal models. ${ }^{1,11,12}$

In Kashmir, Kangri cancer is a well known entity, which develops on inner thighs after chronic use of Kangri. ${ }^{5}$ Our patient also developed SCC at the classical site of Kangri cancer, but also had a subcutaneous non metallic foreign body, probably augmenting the development of SCC.

Acknowledgement: We are grateful to Dr Lateef, lecturer pathology and the theatre staff of dermatology for their help.
Robbins and Cotran: Pathologic basis of disease. 7th ed. Philadelphia, PA: Saunders; 2005: p.122771.

7. Copcu E. Marjolin's ulcer: A preventable complication of burns? Plast Reconstr Surg 2009; 124: 156-64.

8. Okada F. Beyond foreign-body induced carcinogenesis: impact of reactive oxygen species derived from inflammatory cells in tumorigenic conversion and tumor progression. Int J Cancer 2007; 121: 2364-72.

9. Kim HW, Murakami A, Williams MV, Ohigashi H. Suppressive effects of selected antioxidants on the activated leukocytes-induced mutagenesis in the co-culture assay systems. Biosci Biotech Biochem 2004; 68: 238-42.

10. Moizhess TG. Carcinogenesis induced by foreign bodies. Biochemistry (Moscow) 2008; 73: 763 75.

11. Ferguson DJ. Cellular attachment to implanted foreign bodies in relation to tumorigenesis. Cancer Res 1977; 37: 4367-71.

12. Moore GE. Foreign body carcinogenesis. Cancer 1991; 67: 2731-2. 